\title{
A study on important factors influencing innovation in service: A case study of hotel industry
}

\author{
Koorosh Kohyari Haghighat $^{\mathrm{a}^{*}}$, Amir Ghafurian Shagerdi ${ }^{\mathrm{b}}$, Amin Kohyari Haghighat ${ }^{\mathrm{c}}$ and Amin \\ Otoofi $^{\mathrm{c}}$
}

${ }^{a}$ Department of Management and Accounting, Allameh Tabatabai University, Tehran, Iran

${ }^{b}$ Department of Management and Accounting, International University of Imam Reza, Mashhad, Iran

${ }^{c}$ Department of Management and Accounting, Allameh Tabatabai University, Tehran, Iran

\begin{tabular}{|c|c|}
\hline CHRON I C L E & A B S T R A T \\
\hline $\begin{array}{l}\text { Article history: } \\
\text { Received January 30, } 2013 \\
\text { Received in revised format } \\
20 \text { May } 2013 \\
\text { Accepted May } 282013 \\
\text { Available online } \\
\text { May 29 2013 } \\
\text { Keywords: } \\
\text { Purchase intention } \\
\text { Brand trust } \\
\text { Brand familiarity } \\
\text { Perceived value } \\
\text { Perceived risk }\end{array}$ & $\begin{array}{l}\text { Hotel industry plays important role on developing tourism industry and having better services } \\
\text { in this industry always help increase market share. The proposed study of this paper considers } \\
\text { the effects of four variables including collaboration with staff, collaboration with customers, } \\
\text { collaboration with partners and business owners and finally mechanism of integration of } \\
\text { knowledge on innovation on service. The population of this survey includes } 259 \text { hotels where } \\
\text { we send our questionnaire to } 179 \text { and manage to collect } 170 \text { ones. Cronbach alpha for four } \\
\text { variables including collaboration with staff, collaboration with customers, collaboration with } \\
\text { partners and business owners and finally mechanism of integration of knowledge were } \\
\text { calculated as } 0.78,0.865,0.743 \text { and } 0.890 \text {, respectively. The proposed study uses structural } \\
\text { equation modeling to study the relationship between independent variables and dependent } \\
\text { variable and the effects of four variables are confirmed when the level of significance is five } \\
\text { percent. }\end{array}$ \\
\hline
\end{tabular}

\section{Introduction}

Empowering employees plays an important role on increasing innovation in industry (Kirca et al., 2005; Bowen \& Lawler III, 2006; Vargo \& Lusch, 2008). De Man and Duysters, G. (2005) performed a comprehensive review between collaboration and innovation and recommend that a good collaboration among employees could contribute to increase productivity through innovation. Drejer (2004) demonstrated that Schumpeter's original innovation concept was indeed broad enough to encompass services and manufacturing, and that a more direct reference to Schumpeter, more specifically innovation as a contrast to activities based on routine systems, in service oriented studies could contribute a needed theoretical and conceptual strengthening to service innovation studies. 
Atuahene-Gima (1996) investigated the relationship between market orientation and innovation. They presented an empirical investigation of 158 manufacturing and 117 services companies in Australia to investigate the impact of market orientation on innovation characteristics and performance. They reported that market orientation had significant relationships with innovation characteristics such as innovation-marketing fit, product advantage, and inter-functional teamwork but not with product newness and innovation-technology fit. Further, after controlling for the impact of these innovation characteristics, they reported that in both the product and service innovation samples, market orientation made a substantial contribution to the innovation project's effect performance, as measured by its intermediate benefits for the firm. However, it had little impact on its market success, as measured by sales and profit performance. In addition, the results did not confirm the hypothesis that market orientation would have a stronger effect on service innovation performance than on product innovation performance.

According to Chesbrough (2003) open innovation can be considered as the new imperative for creating and profiting from technology. De Luca and Atuahene-Gima (2007) investigated market knowledge dimensions and cross-functional collaboration by examining the different routes to product innovation performance. Gruner and Homburg (2000) reported on research evaluating the performance effect of the intensity of customer interaction in various stages of the new product development process as well as the characteristics of the involved customers. They reported that customer interaction during certain stages (but not others) of the new product development process had a positive effect on new product success. The characteristics of the involved customers had a substantial impact on new product success as well.

According to Hauser et al. (2006), innovation can be considered as one of the most important issues in business research today and it has been studied in various independent research traditions. They performed an investigation on how we can benefit from innovation from an integrative review of these research traditions. They discussed consumer response to innovation, including different techniques to measure consumer innovativeness, techniques of new product growth, and recent ideas on network externalities (Lusch et al., 2007). Li and Calantone (1998) investigated the effect of market knowledge competence on new product advantage through a conceptualization and empirical examination.

Menor et al. (2002) introduced new areas of research to implement innovation to create new value added products. Nijssen et al. (2006) attempted to provide an initial step towards a synthesis of new service and new product development research based a baseline model of innovation. They argued that R\&D strength was more important for new product than service development, while a company's willingness to cannibalize organizational routines and prior investments was more important in the case of new service than new product development (Rust, 1998).

Schulteß et al. (2010) performed an assessment of the current practice of collaborative service innovation in Germany using innovating techniques. Vincent et al. (2004) performed an investigation to find out whether innovation could influence performance of organizations as an intermediate factor. They performed a meta-analysis of determinants and consequences of organizational innovation.

In this paper, we present an empirical investigation to find out the effects of different factors on building innovation within organizations.

\section{The proposed study}

The proposed study of this paper considers the effects of four variables including collaboration with staff, collaboration with customers, collaboration with partners and business owners and finally 
mechanism of integration of knowledge on innovation on service. The proposed study uses the following framework to examine different hypotheses,

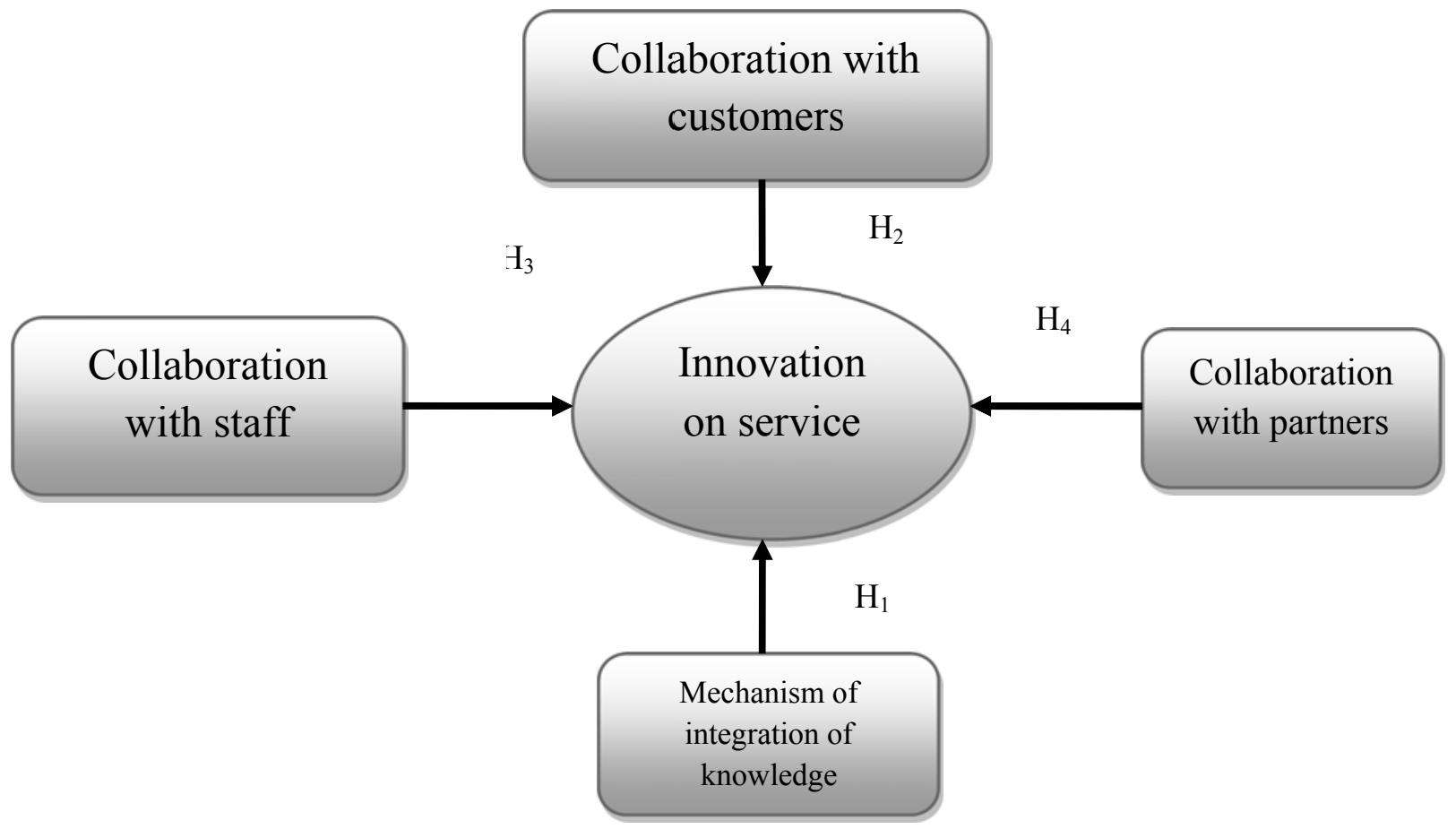

Fig. 1. The proposed study

the following formula to calculate the minimum number of sample size,

$n=\frac{N \times z_{\alpha / 2}^{2} \times p \times q}{\varepsilon^{2} \times(N-1)+z_{\alpha / 2}^{2} \times p \times q}$,

where $N$ is the population size, $p=1-q$ represents the yes/no categories, $z_{\alpha / 2}$ is CDF of normal distribution and finally $\varepsilon$ is the error term. Since we have $p=0.5, z_{\alpha / 2}=1.96$ and $N=259$, the number of sample size is calculated as $n=170$. The proposed study selects 179 Hotels and sent a questionnaire and managed to collect 170 filled ones. Structural equation modeling has been performed to detect important factors influencing innovation on services. There are four hypotheses associated with the proposed study of this paper as follows,

1. Collaboration with staff positively influences on innovation on services.

2. Collaboration with customers positively influences on innovation on services.

3. Collaboration with partners and business owners positively influences on innovation on services.

4. Mechanism of integration of knowledge positively influences on innovation on services.

Cronbach alphas have been calculated for these four mentioned items were well above 0.70 , which validated the overall questionnaire of the survey. Table shows details of Cronbach alpha in preliminary and final stages. 
Table 1

The summary of Cronbach alpha

\begin{tabular}{lcc}
\hline Variable & \# of questions & Final stage \\
\hline Collaboration with staff & 3 & 0.865 \\
Collaboration with customers & 4 & 0.780 \\
Collaboration with partners and business owners & 4 & 0.743 \\
Mechanism of integration of knowledge & 4 & 0.890 \\
\hline Total & 15 & 0.82 \\
\hline
\end{tabular}

The proposed study of this paper uses structural equation modeling to verify different hypotheses of this survey. Fig. 2 shows personal characteristics of the participants. In this study, $43.4 \%$ of the participants were male while $56.6 \%$ were female. In terms of age, $15.2 \%$ of the participants aged 25 years or less, $37.4 \%$ of them aged between 25 and 35 years, $28.8 \%$ of them were $35-45$ years old and $18.6 \%$ of the were older than 50 .

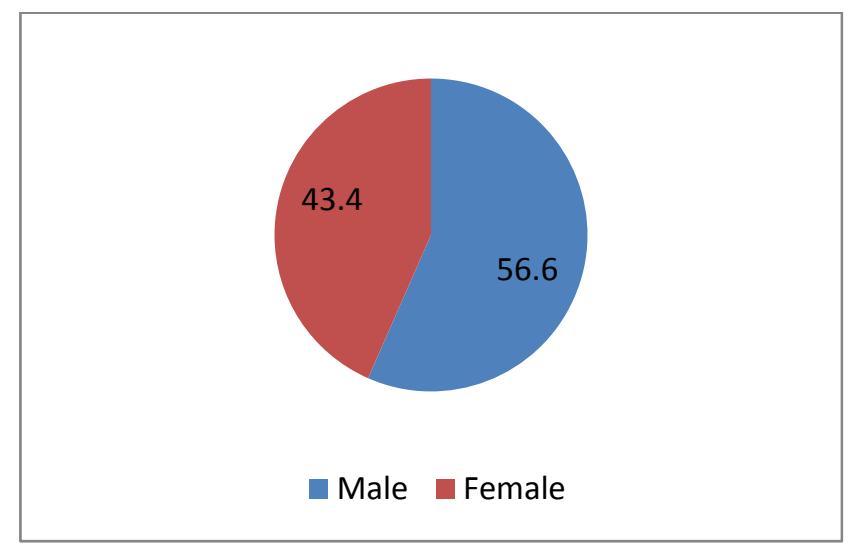

Gender $(\%)$

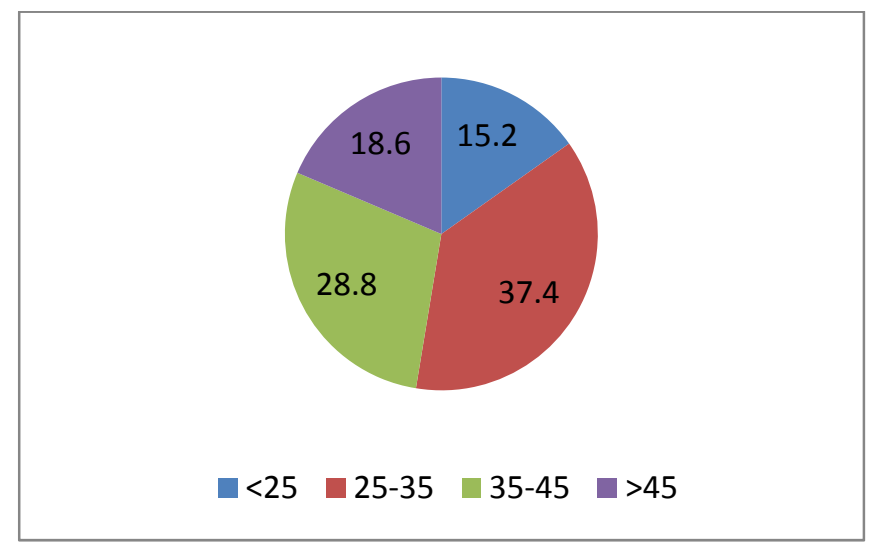

Age (\%)

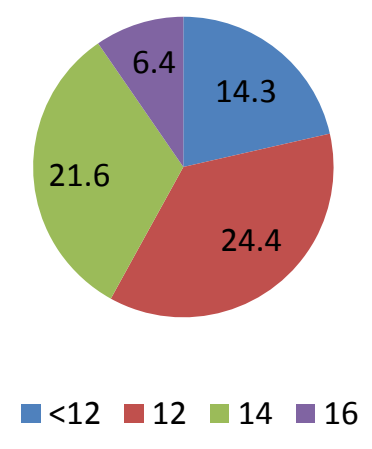

Years of educational background (\%)

Fig. 2. Personal characteristics of the participants

\section{The results}

In this section, we present details of our findings on testing four hypotheses of this paper. Table 2 shows details of our results. The results of Table 2 confirm that all coefficients are statistically significance with $\alpha=5 \%$.

\section{Table 2}

The summary of SEM implementation

\begin{tabular}{lcccc}
\hline Independent var. & Dependent variable & Standard coefficient & t-value & Hypothesis \\
\hline Collaboration with staff & Innovation on services & -0.59 & -3.65 & Confirmed \\
Collaboration with customers & Innovation on services & 0.52 & 10.25 & Confirmed \\
Collaboration with partners and business owners & Innovation on services & 0.47 & 7.49 & Confirmed \\
Mechanism of integration of knowledge & Innovation on services & 0.68 & 6.6 & Confirmed \\
\hline
\end{tabular}




\section{Discussion and conclusion}

In this paper, we have presented an empirical investigation to study the effects of different factors on innovation on services in hoteling industry in Iran. The proposed study designed a questionnaire and examined the impacts of collaboration with staff, collaboration with customers, collaboration with partners and business owners and finally mechanism of integration of knowledge on innovation on service. The results of our survey have confirmed that all independent variables influenced positively on purchasing intention, significantly.

\section{Acknowledgment}

The authors would like to thank all managers who cordially cooperated in accomplishment of this survey. We are also grateful for constructive comments made by anonymous referees, which have significantly contributed to this work.

\section{References}

Alam, I. (2002). An exploratory investigation of user involvement in new service development. Journal of the Academy of Marketing Science, 30(3), 250-261.

Atuahene-Gima, K. (1996). Market orientation and innovation. Journal of Business Research, 35(2), 93-103.

Bowen, D. E., \& Lawler III, E. E. (2006). The empowerment of service workers.Managing innovation and change, 155-69.

Chesbrough, H. W. (2003). Open innovation: The new imperative for creating and profiting from technology. Harvard Business Press.

De Man, A. P., \& Duysters, G. (2005). Collaboration and innovation: a review of the effects of mergers, acquisitions and alliances on innovation. Technovation,25(12), 1377-1387.

De Luca, L. M., \& Atuahene-Gima, K. (2007). Market knowledge dimensions and cross-functional collaboration: examining the different routes to product innovation performance. Journal of Marketing, 95-112.

Drejer, I. (2004). Identifying innovation in surveys of services: a Schumpeterian perspective. Research Policy, 33(3), 551-562.

Gruner, K. E., \& Homburg, C. (2000). Does customer interaction enhance new product success?. Journal of business research, 49(1), 1-14.

Hauser, J., Tellis, G. J., \& Griffin, A. (2006). Research on innovation: A review and agenda for marketing science. Marketing Science, 25(6), 687-717.

Kirca, A. H., Jayachandran, S., \& Bearden, W. O. (2005). Market orientation: a meta-analytic review and assessment of its antecedents and impact on performance. Journal of marketing, 69(2), 24-41.

Li, T., \& Calantone, R. J. (1998). The impact of market knowledge competence on new product advantage: conceptualization and empirical examination. The Journal of Marketing, 13-29.

Lusch, R. F., Vargo, S. L., \& O’Brien, M. (2007). Competing through service: Insights from servicedominant logic. Journal of retailing, 83(1), 5-18.

Menor, L. J., Tatikonda, M. V., \& Sampson, S. E. (2002). New service development: areas for exploitation and exploration. Journal of Operations Management, 20(2), 135-157.

Nijssen, E. J., Hillebrand, B., Vermeulen, P. A., \& Kemp, R. G. (2006). Exploring product and service innovation similarities and differences. International Journal of Research in Marketing, 23(3), 241-251.

Rust, R. (1998). What is the domain of service research?. Journal of Service Research, 1(2), 107-107.

Schulteß, P., Wegener, S., Neus, A., \& Satzger, G. (2010). Innovating for and with your service customers: An assessment of the current practice of collaborative service innovation in Germany. Procedia-Social and Behavioral Sciences, 2(4), 6503-6515. 
Vargo, S. L., \& Lusch, R. F. (2008). Service-dominant logic: continuing the evolution. Journal of the Academy of Marketing Science, 36(1), 1-10.

Vincent, L. H., Bharadwaj, S. G., \& Challagalla, G. N. (2004). Does innovation mediate firm performance?: a meta-analysis of determinants and consequences of organizational innovation. 